\title{
Synthesis, photophysical characterisation and photostability studies of NIR probes with aliphatic, aromatic and chlorinated terminals in 5- and 9-amino positions of benzo[a]phenoxazines
}

B. Rama Raju, ${ }^{\mathrm{a}, \mathrm{b}}$ Marcello M. T. Carvalho, ${ }^{\mathrm{a}}$ Maria Inês P.S. Leitão, ${ }^{\mathrm{a}}$ Paulo J. G. Coutinho, ${ }^{\mathrm{b}}$ and M. Sameiro T. Gonçalves ${ }^{\mathrm{a} *}$

${ }^{a}$ Centre of Chemistry, University of Minho, Campus of Gualtar, 4710-057 Braga, Portugal ${ }^{\mathrm{b}}$ Centre of Physics, University of Minho, Campus of Gualtar, 4710-057 Braga, Portugal
A new series of benzo[ $[a]$ phenoxazinium chlorides possessing mono- or disubstituted amines with 3-chloropropyl groups at the 9- position, isopropyl, cyclohexyl and phenyl groups as terminals at 5-postion was synthesised. Photophysical studies were performed in dry ethanol and aqueous solutions. The photostability of these compounds in different media was also investigated.

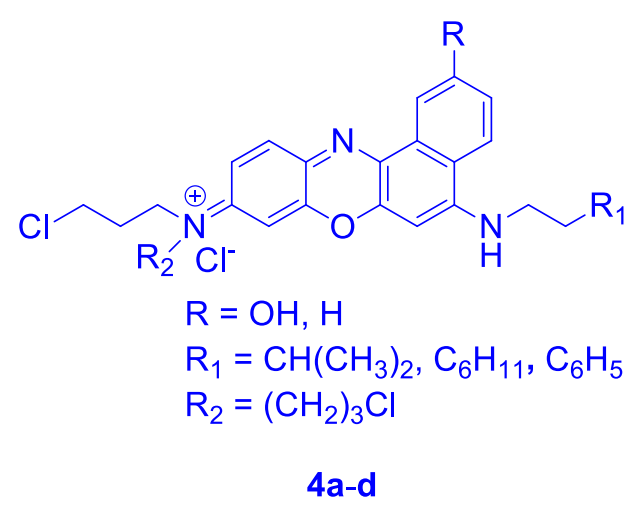




\section{Synthesis, photophysical characterisation and photostability studies of NIR probes with aliphatic, aromatic and chlorinated terminals in 5- and 9-amino positions of benzo[ $[a]$ phenoxazines}

B. Rama Raju, ${ }^{\mathrm{a}, \mathrm{b}}$ Marcello M. T. Carvalho, ${ }^{\mathrm{a}}$ Maria Inês P.S. Leitão, ${ }^{\mathrm{a}}$ Paulo J. G. Coutinho, ${ }^{\mathrm{b}}$ and M. Sameiro T. Gonçalves ${ }^{\mathrm{a} *}$

${ }^{a}$ Centre of Chemistry, University of Minho, Campus of Gualtar, 4710-057 Braga, Portugal ${ }^{\mathrm{b}}$ Centre of Physics, University of Minho, Campus of Gualtar, 4710-057 Braga, Portugal

\section{HIGHLIGHTS}

- A new series of benzo $[a]$ phenoxazinium chlorides was synthesised in moderate yields.

- They exhibit high fluorescence quantum yields in ethanol.

- The fluorochromophores displayed more photostability in biological media and membranes, than in aqueous solutions. 


\title{
Synthesis, photophysical characterisation and photostability studies of NIR probes with aliphatic, aromatic and chlorinated terminals in 5- and 9-amino positions of benzo $[a]$ phenoxazines
}

B. Rama Raju, ${ }^{\mathrm{a}, \mathrm{b}}$ Marcello M. T. Carvalho, ${ }^{\mathrm{a}}$ Maria Inês P.S. Leitão, ${ }^{\mathrm{a}}$ Paulo J. G. Coutinho, ${ }^{\mathrm{b}}$ and M. Sameiro T. Gonçalves ${ }^{\mathrm{a} *}$

${ }^{a}$ Centre of Chemistry, University of Minho, Campus of Gualtar, 4710-057 Braga, Portugal

${ }^{\mathrm{b}}$ Centre of Physics, University of Minho, Campus of Gualtar, 4710-057 Braga, Portugal

\begin{abstract}
A new series of benzo[a]phenoxazinium chlorides possessing mono- or disubstituted amines with 3-chloropropyl groups at the 9-position, isopropyl, cyclohexyl and phenyl groups as terminals at 5-postion was synthesised. Photophysical studies were performed in dry ethanol and aqueous solutions. The terminals at the 5-amino position were found to influence the acidbase equilibrium. The presence of hydroxyl functionality at 2-position was found to introduce an additional basic form that is the one in equilibrium with the cationic acid form in dry ethanol solutions. The photostability of these compounds in different media was also investigated and a high resistance to photobleaching in model biological membranes was observed. In proteins a moderate of $20 \%$ photobleaching occurs in $1 \mathrm{~h} 30 \mathrm{~min}$, while in water more than $60 \%$ of the compound molecules are photodegraded during the same time interval.
\end{abstract}

Keywords: Nile Blue; Benzo[a]phenoxazines; Near-infrared fluorescent probes; Photostability; Fluorochromophores

*Corresponding author. Fax: +351-253604382; E-mail: msameiro@quimica.uminho.pt 


\section{Introduction}

Synthetic fluorescent labels are indispensable tools for quantitative detection in various fields of modern sciences [1]. These are employed in several separation techniques, and are quite remarkable for their fluorescence detection even to the single molecular level as in case of laser-assisted fluorometry [2]. Fluorescence imaging in longer wavelength region (600-1000 $\mathrm{nm})$ is particularly appealing as biomolecules display less background fluorescence and deeper penetration into the substances [3-6]. Several fluorescent dyes reported in the literature suffer from serious drawbacks such as their cumbersome synthesis, limited availability and biological interference [7]. Among the polycylic oxazines, benzo[a]phenoxazinium salts, such as Nile Blue (NB) derivatives are attractive fluorophores due to their sensitivity, photostable nature, high fluorescence quantum yield and in general favourable photophysical properties in the near-infrared spectral region [8]. These compounds are used as fungicide agents [9] and exhibit potent antiprotozoal activities, being even quite effective when attached with substituted phenyl rings to the phenoxazinium skeleton $[10]$. Benzo[a]phenoxazinium chlorides can also function as covalent probes for organic and biological molecules, namely amino acids, proteins, peptides and DNA, as well as in the non-covalent labelling of nucleic acids for use in monitoring changes in protein conformation [11,12], labelling of lysosomes during cell division and apoptosis [13] and imaging tumors that over-express cyclooxygenase-2 [14].

Considering the importance and as a continuation of our current research interest towards the design, synthesis and application of NB derivatives with different substituents [15$25]$, the present work is focused in the preparation of a new set of benzo[a]phenoxazinium chlorides with aliphatic, aromatic and chlorinated terminals in 5- and 9-amino positions of the heteroaromatic system. The photophysical behaviour of these compounds in anhydrous ethanol and in aqueous solutions was investigated along with photostability studies in water and in 
biological medium. These measurements are important for evaluating the suitability of the synthesised compounds as biological markers in imaging applications.

\section{Experimental section}

\subsection{Material and instruments}

All melting points were measured on a Stuart SMP3 melting point apparatus. TLC analysis was carried out on $0.25 \mathrm{~mm}$ thick precoated silica plates (Merck Fertigplatten Kieselgel $60 \mathrm{~F}_{254}$ ) and spots were visualised under UV light. Chromatography on silica gel was carried out on Merck Kieselgel (230-240 mesh). IR spectra were determined on a BOMEM MB 104 spectrophotometer. UV-Vis absorption spectra $(200-800 \mathrm{~nm})$ were obtained using Shimadzu UV/3101PC spectrophotometer and fluorescence spectra with Spex Fluorolog spectrofluorometer. NMR spectra were obtained on a Varian Unity Plus Spectrometer at an operating frequency of $300 \mathrm{MHz}$ for ${ }^{1} \mathrm{H}$ and $75.4 \mathrm{MHz}$ for ${ }^{13} \mathrm{C}$ or a Bruker Avance III 400 at an operating frequency of $400 \mathrm{MHz}$ for ${ }^{1} \mathrm{H}$ and $100.6 \mathrm{MHz}$ for ${ }^{13} \mathrm{C}$ using the solvent peak as internal reference at $25^{\circ} \mathrm{C}$. All chemical shifts are given in ppm using $\delta_{\mathrm{H}} \mathrm{Me}_{4} \mathrm{Si}=0 \mathrm{ppm}$ as reference and $J$ values are given in Hz. Assignments were made by comparison of chemical shifts, peak multiplicities and $J$ values and were supported by spin decoupling-double resonance and bidimensional heteronuclear correlation techniques. Low and high resolution mass spectrometry analysis were performed at the "C.A.C.T.I. - Unidad de Espectrometria de Masas", at University of Vigo, Spain. Photostability studies were carried out using a xenon arc lamp (OSRAM HBO $200 \mathrm{~W}$ ) equipped with a bandpass filter centered $600 \pm 10 \mathrm{~nm}$ (ThorLabs, New Jersey, USA). Commercially available reagents were used as received. 


\subsection{Synthetic method for the preparation of precursor $3 a$}

\subsubsection{5-(Isopentylamino)naphthalen-2-ol 3a}

To a solution of 5-aminonaphthalen-2-ol $(0.477 \mathrm{~g}, 3.0 \mathrm{mmol})$ in ethanol $(2 \mathrm{~mL}), 1$ bromo-3-methylbutane $(0.644 \mathrm{~g}, 3.3 \mathrm{mmol})$ was added, and the resulting mixture was refluxed for 5 hours. The progress of reaction was monitored by TLC (dichloromethane/methanol, 9.5:0.5). After completion of the reaction, the solvent was evaporated and the mixture was purified by column chromatography on silica gel using mixture of dichloromethane and methanol (9.5:0.5) as the eluent. Compound 3a was obtained as colourless solid $(0.528 \mathrm{~g}$, 77\%). mp 111-113 ${ }^{\circ} \mathrm{C} . \quad R_{\mathrm{f}}=0.55$ (dichloromethane/methanol 9.5:0.5). IR $(\operatorname{KBr} 1 \%): v_{\max }=$ 3353, 3062, 2956, 2927, 2869, 1623, 1581, 1531, 1469, 1407, 1368, 1339, 1270, 1219, 1171, 1151, 1027, 996, 957, 862, 813, 795, 772, $743 \mathrm{~cm}^{-1} .{ }^{1} \mathrm{H}$ NMR (CD $\left.{ }_{3} \mathrm{OD}, 400 \mathrm{MHz}\right): \delta_{H} 1.01(\mathrm{~d}$, $J=6.4 \mathrm{~Hz}, 6 \mathrm{H}, \mathrm{NHCH}_{2} \mathrm{CH}_{2} \mathrm{CH}\left(\mathrm{CH}_{3}\right)_{2}, 1.70\left(\mathrm{~m}, 2 \mathrm{H}, \mathrm{NHCH}_{2} \mathrm{CH}_{2} \mathrm{CH}\left(\mathrm{CH}_{3}\right)_{2}\right), 1.76-1.91(\mathrm{~m}, 1 \mathrm{H}$, $\left.\mathrm{NHCH}_{2} \mathrm{CH}_{2} \mathrm{CH}\left(\mathrm{CH}_{3}\right)_{2}\right), 3.28\left(\mathrm{t}, J=7.6 \mathrm{~Hz}, 2 \mathrm{H}, \mathrm{NHCH}_{2} \mathrm{CH}_{2} \mathrm{CH}\left(\mathrm{CH}_{3}\right)_{2}\right), 6.52(\mathrm{~d}, J=7.2 \mathrm{~Hz}$, 1H, 6-H), 7.0-7.06 (m, 2H, 8-H, 3-H), 7.07 (d, $J=2.6 \mathrm{~Hz}, 1 \mathrm{H}, 1-\mathrm{H}), 7.32$ (t, $J=7.6 \mathrm{~Hz}, 1 \mathrm{H}, 7-$ $\mathrm{H}), 7.71(\mathrm{~d}, J=9.2 \mathrm{~Hz}, 1 \mathrm{H}, 4-\mathrm{H}) \mathrm{ppm} .{ }^{13} \mathrm{C} \mathrm{NMR}\left(\mathrm{CD}_{3} \mathrm{OD}, 101.6 \mathrm{MHz}\right): \delta_{C} 22.64$ $\left(\mathrm{NHCH}_{2} \mathrm{CH}_{2} \mathrm{CH}\left(\mathrm{CH}_{3}\right)_{2}\right), 26.19\left(\mathrm{NHCH}_{2} \mathrm{CH}_{2} \mathrm{CH}\left(\mathrm{CH}_{3}\right)_{2}\right), 38.41\left(\mathrm{NHCH}_{2} \mathrm{CH}_{2} \mathrm{CH}\left(\mathrm{CH}_{3}\right)_{2}\right), 42.47$ $\left(\mathrm{NHCH}_{2} \mathrm{CH}_{2} \mathrm{CH}\left(\mathrm{CH}_{3}\right)_{2}\right), 102.78$ (C-6), 110.51 (C-1), 116.01 (C-8 and C-3), 118.74 (C-4a), 121.85 (C-4), 127.49 (C-7), 135.70 (C-8a), 143.73 (C-5), 153.32 (C-2) ppm.

\subsection{General procedure for the synthesis of benzo[a]phenoxazines $\mathbf{4 a - d}$ and $\mathbf{5}$}

To a cold solution (ice bath) of nitrosophenols 1 or $2(1.5 \mathrm{mmol})$ in ethanol $(2 \mathrm{~mL}), 5$ aminonaphthalen-2-ol or naphthalen-1-amine derivatives 3a-d (1.0 mmol) and concentrated hydrochloride acid $(40 \mu \mathrm{L})$ were added. The mixture was refluxed during the time mentioned below, and monitored by TLC. After evaporation of the solvent and column chromatography purification on silica gel with dichloromethane and dichloromethane/methanol, mixtures of 
different polarity, as the eluent, the expected benzo $[a]$ phenoxazines $\mathbf{4 a - d}$ and $\mathbf{5}$ were isolated as blue solids in moderate yields.

2.2.1. 3-Chloro-N-(2-hydroxy-5-(isopentylamino)-9H-benzo[a]phenoxazin-9-ylidene)propan1-aminium chloride $\mathbf{4 a}$

The product of the reaction of 5-((3-chloropropyl)amino)-2-nitrosophenol hydrochloride $1(0.158 \mathrm{~g}, 0.629 \mathrm{mmol})$ in ethanol $(1 \mathrm{~mL})$ and concentrated hydrochloric acid (0.017 mL) with 5-(isopentylamino)naphthalen-2-ol 3a (0.086 g; $0.377 \mathrm{mmol})$ (reflux time 3h) was chromatographed with dichloromethane and dichloromethane/methanol 9.0:1.0 to give compound 4a as a blue solid $(0.166 \mathrm{~g}, \quad 49 \%)$. mp 200-202 ${ }^{\circ} \mathrm{C} . \quad R_{\mathrm{f}}=0.50$ (dichloromethane/methanol, 9:1). IR ( $\mathrm{KBr} 1 \%): v_{\max } 3400,3200,2955,2925,2854,1588$, 1546, 1464, 1324, 1270, 1221, 1155, 1126, 1035, 817, $720 \mathrm{~cm}^{-1} .{ }^{1} \mathrm{H}$ NMR (CD $\left.3 \mathrm{OD}, 400 \mathrm{MHz}\right)$ : $\delta_{H} 1.09\left(\mathrm{~d}, J=6.4 \mathrm{~Hz}, 6 \mathrm{H}, \mathrm{NHCH}_{2} \mathrm{CH}_{2} \mathrm{CH}\left(\mathrm{CH}_{3}\right)_{2}, 1.70-1.85\left(\mathrm{~m}, 4 \mathrm{H}, \mathrm{NHCH}_{2} \mathrm{CH}_{2} \mathrm{CH}\left(\mathrm{CH}_{3}\right)_{2}\right.\right.$ and $\mathrm{NHCH}_{2} \mathrm{CH}_{2} \mathrm{CH}\left(\mathrm{CH}_{3}\right)_{2}$ ), 2.18 (quint, $J=6.4 \mathrm{~Hz}, 2 \mathrm{H}, \mathrm{NHCH}_{2} \mathrm{CH}_{2} \mathrm{CH}_{2} \mathrm{Cl}$ ), 3.51 (t, $J=6.8$ $\left.\mathrm{Hz}, 2 \mathrm{H}, \mathrm{NHCH}_{2} \mathrm{CH}_{2} \mathrm{CH}\left(\mathrm{CH}_{3}\right)_{2}\right), 3.60-3.72\left(\mathrm{~m}, 2 \mathrm{H}, \mathrm{NHCH}_{2} \mathrm{CH}_{2} \mathrm{CH}_{2} \mathrm{Cl}\right), 3.75(\mathrm{t}, J=6.4 \mathrm{~Hz}, 2$ $\left.\mathrm{H}, \mathrm{NHCH}_{2} \mathrm{CH}_{2} \mathrm{CH}_{2} \mathrm{Cl}\right), 6.64$ (s, $\left.1 \mathrm{H}, 6-\mathrm{H}\right), 6.67$ (d, J = $\left.1.6 \mathrm{~Hz}, 1 \mathrm{H}, 8-\mathrm{H}\right), 6.99$ (d, J = 9.2 Hz, 1 H, 10-H), 7.17 (dd, $J=8.8$ and $2.0 \mathrm{~Hz}, 1 \mathrm{H}, 3-\mathrm{H}), 7.63(\mathrm{~d}, J=8.8 \mathrm{~Hz}, 1 \mathrm{H}, 11-\mathrm{H}), 8.0(\mathrm{t}, J=$ $3.2 \mathrm{~Hz}, 1 \mathrm{H}, 1-\mathrm{H}), 8.11(\mathrm{~d}, J=8.8 \mathrm{~Hz}, 1 \mathrm{H}, 4-\mathrm{H}) \mathrm{ppm} .{ }^{13} \mathrm{C} \mathrm{NMR}\left(\mathrm{CD}_{3} \mathrm{OD}, 101.6 \mathrm{MHz}\right): \delta_{C}$ $22.89\left(\mathrm{NHCH}_{2} \mathrm{CH}_{2} \mathrm{CH}\left(\mathrm{CH}_{3}\right)_{2}\right), 23.12\left(\mathrm{NHCH}_{2} \mathrm{CH}_{2} \mathrm{CH}\left(\mathrm{CH}_{3}\right)_{2}\right), 27.45\left(\mathrm{NHCH}_{2} \mathrm{CH}_{2} \mathrm{CH}\left(\mathrm{CH}_{3}\right)_{2}\right)$, $32.62\left(\mathrm{NHCH}_{2} \mathrm{CH}_{2} \mathrm{CH}_{2} \mathrm{Cl}\right), 38.57\left(\mathrm{NHCH}_{2} \mathrm{CH}_{2} \mathrm{CH}\left(\mathrm{CH}_{3}\right)_{2}\right), 41.60\left(\mathrm{NHCH}_{2} \mathrm{CH}_{2} \mathrm{CH}\left(\mathrm{CH}_{3}\right)_{2}\right)$, $43.06\left(\mathrm{NHCH}_{2} \mathrm{CH}_{2} \mathrm{CH}_{2} \mathrm{Cl}\right), 44.21\left(\mathrm{NHCH}_{2} \mathrm{CH}_{2} \mathrm{CH}_{2} \mathrm{Cl}\right), 93.27$ (C-6), 95.85 (C-8), 110.03 (C-1), 117.17 (C-10), 117.29 (Ar-C), 119.51 (Ar-C), 120.12 (C-3), 126.32 (C-4), 130.69 (C-11), 135.07 (2×Ar-C), 135.47 (Ar-C), 153.28 (C-9), 157.38 (Ar-C), 159.45 (C-5), 162.77 (Ar-C) ppm. HRMS: m/z (ESI): Found $[\mathrm{M}]^{+}: 424.17803 ; \mathrm{C}_{24} \mathrm{H}_{27} \mathrm{ClN}_{3} \mathrm{O}_{2}$ requires $[\mathrm{M}]^{+}: 424.17863$. 


\subsubsection{3-Chloro-N-(5-(isopentylamino)-9H-benzo[a]phenoxazin-9-ylidene)propan-1-aminium}

chloride $\mathbf{4 b}$

The product of the reaction of 5-((3-chloropropyl)amino)-2-nitrosophenol hydrochloride $1(0.114 \mathrm{~g}, 0.454 \mathrm{mmol})$ in ethanol $(1 \mathrm{~mL})$ and concentrated hydrochloric acid $(0.012 \mathrm{~mL})$ with $N$-isopentylnaphthalen-1-amine $3 \mathbf{b}(0.058 \mathrm{~g} ; 0.60 \mathrm{mmol})$ (reflux time $8 \mathrm{~h})$ was chromatographed with dichloromethane and dichloromethane/methanol 9.0:1.0 to give compound $\mathbf{4 b}$ as a blue solid $(0.148$ g, 66\% $)$ mp $168-170 \quad{ }^{\circ} \mathrm{C} . \quad R_{\mathrm{f}}=0.58$ (dichloromethane/methanol, 9.5:0.5). IR (KBr 1\%): $v_{\max } 3440,2958,1641,1590,1548,1497$, $1454,1433,1321,1282,1186,1158,1122,999,773 \mathrm{~cm}^{-1} .{ }^{1} \mathrm{H}$ NMR $\left(\mathrm{CD}_{3} \mathrm{OD}, 400 \mathrm{MHz}\right): \delta_{H}$ $1.08\left(\mathrm{~d}, J=6.4 \mathrm{~Hz}, 6 \mathrm{H}, \mathrm{NHCH}_{2} \mathrm{CH}_{2} \mathrm{CH}\left(\mathrm{CH}_{3}\right)_{2}\right), 1.76-1.89\left(\mathrm{~m}, 3 \mathrm{H}, \mathrm{NHCH}_{2} \mathrm{CH}_{2} \mathrm{CH}\left(\mathrm{CH}_{3}\right)_{2}\right.$ and $\left.\mathrm{NHCH}_{2} \mathrm{CH}_{2} \mathrm{CH}\left(\mathrm{CH}_{3}\right)_{2}\right), 2.17-2.26\left(\mathrm{~m}, 2 \mathrm{H}, \mathrm{NHCH}_{2} \mathrm{CH}_{2} \mathrm{CH}_{2} \mathrm{Cl}\right), 3.61(\mathrm{t}, J=6.8 \mathrm{~Hz}, 2 \mathrm{H}$, $\left.\mathrm{NHCH}_{2} \mathrm{CH}_{2} \mathrm{CH}\left(\mathrm{CH}_{3}\right)_{2}\right), 3.74-3.83\left(\mathrm{~m}, 4 \mathrm{H}, \mathrm{NHCH}_{2} \mathrm{CH}_{2} \mathrm{CH}_{2} \mathrm{Cl}\right.$ and $\left.\mathrm{NHCH}_{2} \mathrm{CH}_{2} \mathrm{CH}_{2} \mathrm{Cl}\right), 6.90$ (s, $1 \mathrm{H}, 8-\mathrm{H}), 7.03(\mathrm{~s}, 1 \mathrm{H}, 6-\mathrm{H}), 7.15(\mathrm{~d}, J=8.4 \mathrm{~Hz}, 1 \mathrm{H}, 10-\mathrm{H}), 7.82-7.92(\mathrm{~m}, 2 \mathrm{H}, 11-\mathrm{H}$ and 3-H), 7.97 (t, $J=7.6 \mathrm{~Hz}, 1 \mathrm{H}, 2-\mathrm{H}), 8.39$ (d, $J=8.4 \mathrm{~Hz}, 1 \mathrm{H}, 4-\mathrm{H}), 8.98$ (d, $J=7.6 \mathrm{~Hz}, 1 \mathrm{H}, 1-$ H) ppm. ${ }^{13} \mathrm{C} \quad \mathrm{NMR} \quad\left(\mathrm{CD}_{3} \mathrm{OD}, \quad 100.6 \mathrm{MHz}\right): \delta_{\mathrm{C}} 22.82 \quad\left(\mathrm{NHCH}_{2} \mathrm{CH}_{2} \mathrm{CH}\left(\mathrm{CH}_{3}\right)_{2}\right), \quad 22.91$ $\left(\mathrm{NHCH}_{2} \mathrm{CH}_{2} \mathrm{CH}\left(\mathrm{CH}_{3}\right)_{2}\right), 27.42\left(\mathrm{NHCH}_{2} \mathrm{CH}_{2} \mathrm{CH}\left(\mathrm{CH}_{3}\right)_{2}\right), 32.63\left(\mathrm{NHCH}_{2} \mathrm{CH}_{2} \mathrm{CH}_{2} \mathrm{Cl}\right), \quad 38.35$ $\left(\mathrm{NHCH}_{2} \mathrm{CH}_{2} \mathrm{CH}\left(\mathrm{CH}_{3}\right)_{2}\right), 41.64\left(\mathrm{NHCH}_{2} \mathrm{CH}_{2} \mathrm{CH}\left(\mathrm{CH}_{3}\right)_{2}\right), 42.95\left(\mathrm{NHCH}_{2} \mathrm{CH}_{2} \mathrm{CH}_{2} \mathrm{Cl}\right), 44.30$ $\left(\mathrm{NHCH}_{2} \mathrm{CH}_{2} \mathrm{CH}_{2} \mathrm{Cl}\right), 92.39$ (C-6), 95.86 (C-8), 123.84 (C-4), 125.03 (C-10), 125.76 (C-1), 131.11 (C-3), 132.02 (Ar-C), 132.79 (2×Ar-C), 133.09 (C-2), 134.02 (C-11), 135.39 (2×Ar-C), 153.53 (C-9), 158.0 (Ar-C), 159.63 (C-5) ppm. HRMS: m/z (ESI): Found [M] $]^{+}: 408.18308$; $\mathrm{C}_{24} \mathrm{H}_{27} \mathrm{ClN}_{3} \mathrm{O}$ requires $[\mathrm{M}]^{+}: 408.18372$.

2.2.3. 3-Chloro-N-(5-((2-cyclohexylethyl)amino)-9H-benzo[a]phenoxazin-9-ylidene)propan-1aminium chloride $\mathbf{4 c}$

The product of the reaction of 5-((3-chloropropyl)amino)-2-nitrosophenol hydrochloride $1(0.136 \mathrm{~g}, 0.541 \mathrm{mmol})$ in ethanol $(1 \mathrm{~mL})$ and concentrated hydrochloric acid 
(0.013 mL) with $N$-(2-cyclohexylethyl)naphthalen-1-amine 3c (0.082 g; $0.325 \mathrm{mmol})$ (reflux time 3h) was chromatographed with dichloromethane and dichloromethane/methanol 9.0:1.0 to give compound $4 \mathrm{c}$ as a blue solid $(0.118 \mathrm{~g}, \quad 52 \%)$ mp $248-250{ }^{\circ} \mathrm{C} . \quad R_{\mathrm{f}}=0.43$ (dichloromethane/methanol, 9:1). IR (KBr 1\%): $v_{\max } 3444,2926,1640,1588,1548,1493$, $1448,1431,1317,1268,1202,1157,1122,998,819,773 \mathrm{~cm}^{-1} .{ }^{1} \mathrm{H}$ NMR $\delta_{H}\left(\mathrm{CD}_{3} \mathrm{OD}, 400\right.$ $\mathrm{MHz}), 1.0-1.60$ (3×m, 9H, CH Cy), 1.62-1.80 (m, 2H, $\left.\mathrm{NHCH}_{2} \mathrm{CH}_{2} \mathrm{C}_{6} \mathrm{H}_{11}\right), 1.81-1.90$ (m, 2H, CH Cy), 2.10-2.25 (m, 2H, $\mathrm{NHCH}_{2} \mathrm{CH}_{2} \mathrm{CH}_{2} \mathrm{Cl}$ ), 3.40-3.60 (m, 2H, $\mathrm{NHCH}_{2} \mathrm{CH}_{2} \mathrm{CH}_{2} \mathrm{Cl}$ ), 3.62$3.85\left(\mathrm{~m}, 4 \mathrm{H}, \mathrm{NHCH}_{2} \mathrm{CH}_{2} \mathrm{CH}_{2} \mathrm{Cl}\right.$ and $\left.\mathrm{NHCH}_{2} \mathrm{CH}_{2} \mathrm{C}_{6} \mathrm{H}_{11}\right), 6.82(\mathrm{~d}, J=2.0 \mathrm{~Hz}, 1 \mathrm{H}, 8-\mathrm{H}), 6.92$ (s, $1 \mathrm{H}, 6-\mathrm{H}), 7.11$ (dd, $J=9.0$ and $1.6 \mathrm{~Hz}, 1 \mathrm{H}, 10-\mathrm{H}), 7.77-7.86(\mathrm{~m}, 2 \mathrm{H}, 11-\mathrm{H}$ and 3-H), 7.93 $(\mathrm{t}, J=8.0 \mathrm{~Hz}, 1 \mathrm{H}, 2-\mathrm{H}), 8.34(\mathrm{~d}, J=8.0 \mathrm{~Hz}, 1 \mathrm{H}, 4-\mathrm{H}), 8.90(\mathrm{~d}, J=8.0 \mathrm{~Hz}, 1 \mathrm{H}, 1-\mathrm{H}) \mathrm{ppm} .{ }^{13} \mathrm{C}$ NMR $\delta_{C}\left(\mathrm{CD}_{3} \mathrm{OD}, 100.6 \mathrm{MHz}\right), 27.33(\mathrm{CH} \mathrm{Cy}), 27.41(\mathrm{CH} \mathrm{Cy}), 27.55\left(\mathrm{CH}_{2} \mathrm{Cy}\right), 32.61\left(\mathrm{CH}_{2}\right.$ Cy), $33.08\left(\mathrm{NHCH}_{2} \mathrm{CH}_{2} \mathrm{CH}_{2} \mathrm{Cl}\right), 34.31\left(\mathrm{CH}_{2} \mathrm{Cy}\right), 36.98\left(\mathrm{NHCH}_{2} \mathrm{CH}_{2} \mathrm{C}_{6} \mathrm{H}_{11}\right.$ and $\left.\mathrm{CH} \mathrm{Cy}\right), 41.68$ $\left(\mathrm{NHCH}_{2} \mathrm{CH}_{2} \mathrm{CH}_{2} \mathrm{Cl}\right), 43.00\left(\mathrm{NHCH}_{2} \mathrm{CH}_{2} \mathrm{CH}_{2} \mathrm{Cl}\right), 43.88\left(\mathrm{NHCH}_{2} \mathrm{CH}_{2} \mathrm{C}_{6} \mathrm{H}_{11}\right), 94.34$ (C-6), 95.60 (C-8), 123.84 (Ar-C), 124.25 (Ar-C), 124.92 (C-4), 125.67 (C-1), 126.10 (Ar-C), 131.07 (C-3), 131.83 (Ar-C), 131.91 (Ar-C), 132.62 (C-2), 133.04 (Ar-C), 133.69 (Ar-C), 133.96 (C11), 135.20 (Ar-C), 153.29 (Ar-C), 157.93 (C-9), 159.40 (C-5) ppm. HRMS: m/z (ESI): Found $[\mathrm{M}]^{+}:$448.21449; $\mathrm{C}_{27} \mathrm{H}_{31} \mathrm{ClN}_{3} \mathrm{O}$ requires $[\mathrm{M}]^{+}: 448.21502$.

\subsubsection{3-Chloro-N-(5-(phenethylamino)-9H-benzo[a]phenoxazin-9-ylidene)propan-1-aminium} 4d

The product of the reaction of 5-((3-chloropropyl)amino)-2-nitrosophenol hydrochloride $1(0.116 \mathrm{~g}, 0.462 \mathrm{mmol})$ in ethanol $(1 \mathrm{~mL})$ and concentrated hydrochloric acid (0.011 mL) with $N$-phenethylnaphthalen-1-amine 3d (0.068 g; $0.277 \mathrm{mmol})$ (reflux time 3h) was chromatographed with dichloromethane and dichloromethane/methanol 9.0:1.0 to give compound $\mathbf{4 c}$ as a blue solid $(0.092 \mathrm{~g}, \quad 40 \%)$. mp $220-222 \quad{ }^{\circ} \mathrm{C} . \quad R_{\mathrm{f}}=0.52$ (dichloromethane/methanol, 9:1). IR ( $\mathrm{KBr} 1 \%): v_{\max } 3420,2925,2855,1639,1583,1543$, 
$1492,1450,1432,1313,1287,1259,1172,1154,1124,994,828,773,738 \mathrm{~cm}^{-1} .{ }^{1} \mathrm{H}$ NMR $\delta_{H}$ $\left(\mathrm{CD}_{3} \mathrm{OD}, 400 \mathrm{MHz}\right), 1.36\left(\mathrm{~m}, 2 \mathrm{H}, \mathrm{NHCH}_{2} \mathrm{CH}_{2} \mathrm{CH}_{2} \mathrm{Cl}\right), 3.17(\mathrm{t}, J=7.2 \mathrm{~Hz}, 2 \mathrm{H}$, $\left.\mathrm{NHCH}_{2} \mathrm{CH}_{2} \mathrm{C}_{6} \mathrm{H}_{5}\right), 3.58\left(\mathrm{t}, J=6.8 \mathrm{~Hz}, 2 \mathrm{H}, \mathrm{NHCH}_{2} \mathrm{CH}_{2} \mathrm{C}_{6} \mathrm{H}_{5}\right), 3.76(\mathrm{t}, J=6.4 \mathrm{~Hz}, 2 \mathrm{H}$, $\mathrm{NHCH}_{2} \mathrm{CH}_{2} \mathrm{CH}_{2} \mathrm{Cl}$ ), 3.99 (t, $J=7.2 \mathrm{~Hz}, 2 \mathrm{H}, \mathrm{NHCH}_{2} \mathrm{CH}_{2} \mathrm{CH}_{2} \mathrm{Cl}$ ), 6.82 (s, $\left.1 \mathrm{H}, \mathrm{H}-8\right), 6.90$ (s, 1 H, 6-H), 7.12 (dd, $J=9.2$ and $2.0 \mathrm{~Hz}, 1 \mathrm{H}, 10-\mathrm{H}), 7.20-7.24(\mathrm{~m}, 1 \mathrm{H}, \mathrm{Ar}-\mathrm{H}), 7.28-7.36(\mathrm{~m}, 4 \mathrm{H}$, 4×Ar-H), 7.79-7.89 (m, $2 \mathrm{H}, 11-\mathrm{H}$ and 3-H), $7.92(\mathrm{t}, J=7.6 \mathrm{~Hz}, 1 \mathrm{H}, 2-\mathrm{H}), 8.29(\mathrm{~d}, J=8,0 \mathrm{~Hz}$, $1 \mathrm{H}, 4-\mathrm{H}), 8.90(\mathrm{~d}, J=7.2 \mathrm{~Hz}, 1 \mathrm{H}, 1-\mathrm{H}) \mathrm{ppm} .{ }^{13} \mathrm{C}$ NMR $\delta_{C}\left(\mathrm{CD}_{3} \mathrm{OD}, 100.6 \mathrm{MHz}\right), 32.61$

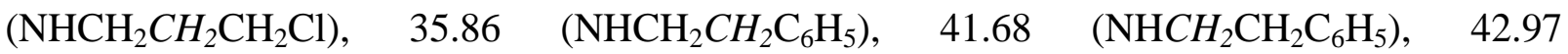
$\left(\mathrm{NH}_{2} \mathrm{CH}_{2} \mathrm{CH}_{2} \mathrm{CH}_{2} \mathrm{Cl}\right), 47.12\left(\mathrm{NHCH}_{2} \mathrm{CH}_{2} \mathrm{CH}_{2} \mathrm{Cl}\right), 94.53$ (C-6), 95.53 (C-8), 123.75 (C-4), 124.86 (C-10), 125.68 (C-1), 129.82 (Ar-C), 129.86 (Ar-C), 130.09 (2×Ar-C), 130.77 (Ar-C), 131.05 (C-3), 132.08 (Ar-C), 132.40 (1×Ar-C), 132.65 (Ar-C), 133.03 (C-2), 133.59 (Ar-C), 134.04 (C-11), 135.10 (Ar-C), 139.39 (Ar-C), 153.20 (C-9), 158.03 (Ar-C), 159.51 (C-5) ppm. HRMS: m/z (ESI): Found $[\mathrm{M}]^{+}:$442.16734; $\mathrm{C}_{27} \mathrm{H}_{25} \mathrm{ClN}_{3} \mathrm{O}$ requires $[\mathrm{M}]^{+}: 442.16807$.

\subsubsection{3-Chloro-N-(3-chloropropyl)-N-(5-(isopentylamino)-9H-benzo[a]phenoxazin-9-ylidene)} propan-1-aminium chloride $\mathbf{5}$

The product of the reaction of 5-(bis(3-chloropropyl)amino)-2-nitrosophenol hydrochloride $2(0.113 \mathrm{~g}, 0.345 \mathrm{mmol})$ in ethanol $(1 \mathrm{~mL})$ and concentrated hydrochloric acid $(0.008 \mathrm{~mL})$ with $N$-isopentylnaphthalen-1-amine $3 \mathbf{b}(0.044 \mathrm{~g}, 0.60 \mathrm{mmol})$ (reflux time $3 \mathrm{~h})$ was chromatographed with dichloromethane and dichloromethane/methanol 9.0:1.0 to give compound $\mathbf{5}$ as a blue solid $(0.133 \mathrm{~g}, \quad 58 \%)$. $\mathrm{mp} \quad 221-223{ }^{\circ} \mathrm{C} . \quad R_{\mathrm{f}}=0.14$ (dichloromethane/methanol, 9.5:0.5). FTIR (KBr 1\%): $v_{\max }$ 2956, 1639, 1587, 1546, 1491, 1456, 1434, 1330, 1279, 1220, 1178, 1159, 1123, 999, $775 \mathrm{~cm}^{-1} .{ }^{1} \mathrm{H}$ NMR $\left(\mathrm{CD}_{3} \mathrm{OD}, 400 \mathrm{MHz}\right)$ : $\delta_{H} 1.08\left(\mathrm{~d}, J=6.0 \mathrm{~Hz}, 6 \mathrm{H}, \mathrm{NHCH}_{2} \mathrm{CH}_{2} \mathrm{CH}\left(\mathrm{CH}_{3}\right)_{2}\right), 1.75-1.90\left(\mathrm{~m}, 3 \mathrm{H}, \mathrm{NHCH}_{2} \mathrm{CH}_{2} \mathrm{CH}\left(\mathrm{CH}_{3}\right)_{2}\right.$ and $\left.\mathrm{NHCH}_{2} \mathrm{CH}_{2} \mathrm{CH}\left(\mathrm{CH}_{3}\right)_{2}\right), 2.19-2.30\left(\mathrm{~m}, 4 \mathrm{H}, \mathrm{N}\left(\mathrm{CH}_{2} \mathrm{CH}_{2} \mathrm{CH}_{2} \mathrm{Cl}\right)_{2}\right), 3.73-3.90(\mathrm{~m}, 10 \mathrm{H}$, $\left.\mathrm{NHCH}_{2} \mathrm{CH}_{2} \mathrm{CH}\left(\mathrm{CH}_{3}\right)_{2}, \mathrm{~N}\left(\mathrm{CH}_{2} \mathrm{CH}_{2} \mathrm{CH}_{2} \mathrm{Cl}\right)_{2}\right)$ and $\left.\mathrm{N}\left(\mathrm{CH}_{2} \mathrm{CH}_{2} \mathrm{CH}_{2} \mathrm{Cl}\right)_{2}\right), 7.04$ (s, $2 \mathrm{H}, 8-\mathrm{H}$ and 6- 
H), $7.34(\mathrm{~d}, J=8.8 \mathrm{~Hz}, 1 \mathrm{H}, 10-\mathrm{H}), 7.87(\mathrm{t}, J=7.2 \mathrm{~Hz}, 1 \mathrm{H}, 3-\mathrm{H}), 7.92-8.02(\mathrm{~m}, 2 \mathrm{H}, 2-\mathrm{H}$ and $11-\mathrm{H}), 8.40(\mathrm{~d}, J=8.0 \mathrm{~Hz}, 1 \mathrm{H}, 1-\mathrm{H}), 8.96(\mathrm{~d}, J=8.0 \mathrm{~Hz}, 1 \mathrm{H}, 4-\mathrm{H}) \mathrm{ppm} .{ }^{13} \mathrm{C} \mathrm{NMR}\left(\mathrm{CD}_{3} \mathrm{OD}\right.$, $100.6 \mathrm{MHz}): \quad \delta_{\mathrm{C}} 22.82 \quad\left(\mathrm{NHCH}_{2} \mathrm{CH}_{2} \mathrm{CH}\left(\mathrm{CH}_{3}\right)_{2}\right), \quad 27.41 \quad\left(\mathrm{NHCH}_{2} \mathrm{CH}_{2} \mathrm{CH}\left(\mathrm{CH}_{3}\right)_{2}\right), \quad 31.36$ $\left(\mathrm{N}\left(\mathrm{CH}_{2} \mathrm{CH}_{2} \mathrm{CH}_{2} \mathrm{Cl}\right)_{2}\right), 38.39\left(\mathrm{NHCH}_{2} \mathrm{CH}_{2} \mathrm{CH}\left(\mathrm{CH}_{3}\right)_{2}\right), 43.15\left(\mathrm{NHCH}_{2} \mathrm{CH}_{2} \mathrm{CH}\left(\mathrm{CH}_{3}\right)_{2}\right), 44.49$

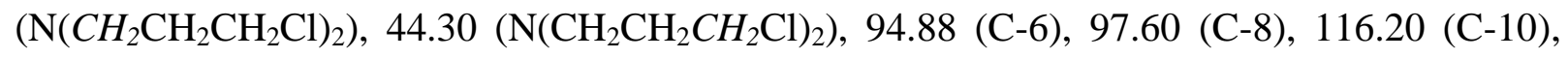
124.01 (C-1), 125.11 (Ar-C), 125.91 (C-4), 131.17 (Ar-C), 131.40 (C-3), 132.71 (Ar-C), 133.34 (C-2), 133.99 (C-11), 136.60 (Ar-C), 149.44 (Ar-C), 153.76 (C-9), 155.62 (Ar-C), 160.11 (C-5) ppm. HRMS: m/z (ESI): Found $[\mathrm{M}]^{+}:$484.19154; $\mathrm{C}_{27} \mathrm{H}_{32} \mathrm{Cl}_{2} \mathrm{~N}_{3} \mathrm{O}$ requires [M] ${ }^{+}$: 484.19169.

2.3. Typical procedure for the photostablity studies with benzo[a]phenoxazinium chlorides $\mathbf{4 b}$ and 5 .

Solutions of the compounds $\mathbf{4 b}$ and $\mathbf{5}\left(\mathrm{C}=1 \times 10^{-5} \mathrm{M}\right)$ was prepared in ethanol, water, buffered solutions of BSA and membranes (soya lecithin) in a $5 \mathrm{~mL}$ flask. Then a volume of 2 mL was pipetted into a quartz cuvette and placed directly in the path of incident light with an irradiance of $10 \mathrm{mWcm}^{-2}$ (Xenon arc lamp, OSRAM HBO $200 \mathrm{~W}$ ) equipped with a band pass filter centered on $600 \pm 10 \mathrm{~nm}$ (ThorLabs, New Jersey, USA). The absorbance was recorded from the initial $(\mathrm{t}=0 \mathrm{~min})$ to the maximum $(\mathrm{t}=110 \mathrm{~min})$ irradiation with various time intervals in between.

\section{Results and discussion}

\subsection{Synthetic methods}

The synthesis of benzo[a]phenoxazinium chlorides $\mathbf{4 a - d}$ and $\mathbf{5}$ was initiated with the preparation of $\mathrm{N}$-alkylated derivatives of 3-aminophenol, 5-aminonaphthalen-2-ol and 
naphthalen-1-amine. The reaction of 3-aminophenol with 1-bromo-3-chloropropane followed by silica gel column chromatography purification afforded 3-(3-chloropropylamino)phenol and 3-(bis(3-chloropropyl)amino)phenol, respectively. The nitrosation of these compounds was carried out with sodium nitrite in hydrochloric acidic solution to obtain 5-(3chloropropylamino)-2-nitrosophenol hydrochloride $\mathbf{1}$ and 5-(bis(3-chloropropyl)amino)-2nitrosophenol hydrochloride 2 [15].

The 5-(isopentylamino)naphthalen-2-ol 3a was obtained by the $N$-alkylation reaction of 5-aminonaphthalen-2-ol with 1-bromo-3-methylbutane in ethanol under reflux conditions. Similarly, the precursors $\quad N$-isopentyl-naphthalen-1-amine $\quad 3 b, \quad N$-(2cyclohexylethyl)naphthalen-1-amine $\quad \mathbf{3 c}$ and $N$-(phenethyl)naphthalen-1-amine $\mathbf{3 d}$ were synthesised by the reaction of naphthalen-1-amine with 1-bromo-3-methylbutane, (2bromoethyl)cyclohexane and (2-bromoethyl)benzene in ethanol following the procedure described [16]. After purification by silica gel column chromatography, intermediates 3a-d were isolated and spectroscopic data were in accordance with the expected structures.

The reaction of 3-(3-chloropropylamino)phenol hydrochloride 1 or 3-(bis(3chloropropyl)amino)phenol hydrochloride $\mathbf{2}$ with $\mathrm{N}$-alkylated derivatives of 5aminonaphthalen-2-ol and naphthalen-1-amine 3a-d in an acidic medium afforded the corresponding benzo $[a]$ phenoxazinium chlorides $\mathbf{4 a - d}$ and $\mathbf{5}$, respectively (Scheme 1 ). Thus, reaction of nitrosophenol $\mathbf{1}$ with intermediates 3a-d in ethanol, in the presence of concentrated hydrochloric acid, and after silica gel column chromatography purification gave the benzo $[a]$ phenoxazinium chlorides 4a-d, possessing the isopropyl, cyclohexyl and phenyl terminals at 5-position, monosubstituted with the 3-chloropropyl group at the amine of 9position. Similarly, the nitrosophenol 2 reacted with precursors 3a, producing the cationic dye 5, but with the amino of 9-position of the polycyclic system disubstituted with 3-chloropropyl groups. All these compounds were obtained as blue solids in moderate yields and were fully 
characterised by high resolution mass spectrometry, IR and NMR $\left({ }^{1} \mathrm{H}\right.$ and $\left.{ }^{13} \mathrm{C}\right)$ spectroscopy (Table 1).

\section{$<$ Scheme 1>}

\subsection{Physical studies}

Electronic absorption and fluorescence spectra of solutions of fluorophores $\mathbf{4 a - d}$ and $\mathbf{5}$ in absolute ethanol and water were measured at various concentrations. Summarised data of this study is presented in Table 1 .

\section{$<$ Table 1>}

The fluorescence quantum yields $\Phi_{\mathrm{F}}$ were evaluated using oxazine 1 in ethanol as standard $\left(\Phi_{\mathrm{F}}=0.11\right)[26]$ at $575 \mathrm{~nm}$ or $470 \mathrm{~nm}$ excitation.

Figure 1 shows absorption and fluorescence spectra, at $470 \mathrm{~nm}$ excitation, of the compounds in water (panels A and B), ethanol (panels C and D) and basified (addition of a small amount of tetraethylammonium hydroxide) or acidified (addition of a small amount of trifluoroacetic acid) ethanol (panels E and F).

Previous studies of benzo[ $a]$ phenoxazinium chloride derivatives $[27,28]$ showed that the absorption spectra in ethanol media is composed of two contributions. The acidic form $\left(\mathrm{BzH}^{+}\right)$and other, that is the neutral form $(\mathrm{Bz})$, which is $\sim 100 \mathrm{~nm}$ blue shifted. This is clearly seen in Figure 1C and from the distinct behaviour in basified or acidified ethanol (Figure 1E).

\section{<Figure 1>}


In ethanol media, compound $\mathbf{5}$ which is di-alkylated at 9-aminoposition, shows a higher fraction of basic form. Globally, when comparing with similar compounds without a bulky group at the terminal of 5-amino position [15], it is possible to conclude that the bulky groups used in this study, significantly increase the fraction of basic form. The absorption spectra of compound $4 \mathbf{a}$, possessing $\mathrm{OH}$ functionality at position 2 , shows a very distinct behaviour. It can be seen that in basified ethanol the usual neutral form appears (Figure 1E) with a slight blue shift whereas in normal ethanol what would be the contribution from that form appears deviated more than $50 \mathrm{~nm}$ in comparison with the other compounds (Figure 1C). This deviation can be understood by considering an additional form that corresponds to deprotonation of the $\mathrm{OH}$ group with possible interaction, by H-bond, with solvent molecules. In that basic form the $\pi$-conjugation system would not be significantly changed resulting in a less blue shifted absorption than when the deprotonation occurs at the 5-position. As in previous studies [15, 17], compound 5 shows that double alkylation at 9-position results in red shift of the acid form absorption.

In water media, as observed in our previous studies for similar compounds [15, 27, 28], non-emissive $\mathrm{H}$-aggregates of the acidic form are observed as a blue shoulder around $600 \mathrm{~nm}$ or as a flat absorption band (Figure 1A). The aggregation fraction increases with compound concentration resulting in corresponding spectral changes. This has been seen in previous studies on this type of compounds and also occurs for these compounds $\mathbf{4 a - d}$ and $\mathbf{5}$ (data not shown).

Variations in the absorption spectra of these compounds in anhydrous ethanol with its concentration corresponds to changing ratios of the acid and basic forms of the compounds as can be concluded from Figure 2. Typical variations are shown in Figure $2 \mathrm{~B}$ being that, as stated previously, compound $\mathbf{4 a}$ behaves differently (Figure 2A). 
With the exception of compound $\mathbf{4 a}$, the experimental spectra were fitted to a weighted sum of the spectra obtained in acidified and basified ethanol. For compound $\mathbf{4 a}$, the spectrum of the basic form was defined by a sum of two Gaussian functions. Figures $2 \mathrm{~A}$ and $2 \mathrm{~B}$ shows the result of this fitting procedure together with the used spectra of acid and basic forms.

Considering that acid and basic forms are at chemical equilibrium, the following equation can be derived for the fraction of basic form, $f_{b}$ :

$$
\frac{\left(1-f_{b}\right)}{f_{b}} K_{a}-\frac{f_{b} C_{T}}{2}+\sqrt{\left(\frac{f_{b} C_{T}}{2}\right)^{2}+K_{E t O H}}=0
$$

where $\mathrm{C}_{\mathrm{T}}$ is the compound total concentration, $\mathrm{K}_{\mathrm{a}}$, is the dissociation constant and $\mathrm{K}_{\mathrm{EtOH}}$ is ethanol self-dissociation constant. This model was previously and successfully applied in compounds of the same family $[17,28]$. In Figure $2 \mathrm{C}$ it is shown that the fitting of the fraction of basic form, obtained from spectral deconvolution procedure, with eq. (1). In Table 2 the resulting equilibrium constants are reported for an ethanol self-dissociation constant of $7.97 \times 10^{-13} \mathrm{M}^{2}$, obtained globally for all data in Figure 2C. As in a previous study [17] the value of the ionic product corresponding to the ethanol self-dissociation equilibrium is much higher than expected [29] and, as stated therein, can probably be accounted from specific interactions of the studied compound with ethanol solvating molecules. For compounds without substitution at the 2-position and monosubstitued at the 9-amino position, the obtained $\mathrm{K}_{\mathrm{a}}$ values follows the order cyclohexyl < benzyl < isopropyl which seems related to decreasing order of steric hindrance in the terminal at the 5-amino position. Disubstitution at the 9-amino position has already been reported to increase the dissociation equilibrium constant [17].

\section{<Table 2>}


The fluorescence spectra in ethanol (Figures 1D and 1F) shows that, with the exception of compound $\mathbf{4 a}$, it is possible to completely displace the acid-base equilibrium into the basic form by the addition of TEAH. As already reported for similar compounds [27, 28], the basic form has a broad fluorescence band centered at $\sim 610 \mathrm{~nm}$. The calculated quantum yields are located between 0.019 and 0.027 (Table 1). For compound $4 \mathbf{a}$ a very low and broad emission is observed indicating that the hydroxyl group at the 2-position has a profound effect on the emission of the neutral basic form of this family of compounds.

In order to fully displace the acid-base equilibrium into the acid form TFA was added to the ethanolic solution. However, two types of emission bands were observed (Figure 1F) upon excitation with $470 \mathrm{~nm}$ wavelength. From previous studies $[15,27,28]$, the band centered between 644-666 $\mathrm{nm}$ with a high quantum yield corresponds to the acid form emission. The other, near $540 \mathrm{~nm}$, has recently been attributed to a tautomeric form (proton displacement resulting in localization of the positive charge in one of the 5- or 9-amino positions) with the corresponding excitation spectrum showing absorption at $\sim 510 \mathrm{~nm}$ and $\sim 480 \mathrm{~nm}$ [15]. These bands are not seen in the absorption spectra in acidified ethanol (Figure 1E) so that the impact of the tautomerization process on the quantification of the acid-base equilibria (Table 2) should be very low. Only in compounds $\mathbf{4 a}$ and $\mathbf{5}$ the tautomeric forms are absent so that the tabulated values of the quantum yields of these compounds are $38 \%$ and $44 \%$ respectively, which should be close to the actual values. For the other compounds, the calculated quantum yields with an excitation wavelength of $575 \mathrm{~nm}$ at which only the acid form emission is recorded, increases from ethanol to acidified ethanol. This is expected as the fraction of basic form which has low quantum yield reduces practically to zero upon acidification with TFA (Figure 1E). Those quantum yields lies between $45 \%$ and $47 \%$ and expected to be very close to the actual values as the tautomeric forms were not detected in the absorption spectra in acidified ethanol.

In water, only small amounts of tautomer emission was observed for compounds $\mathbf{4 b}$ and 4a (Figure 1B). Considering that no basic form is observed in the corresponding absorption 
spectrum (Figure 1A) and also the existing H-aggregates are non-emissive, the obtained values of fluorescence quantum yield are the actual values for the acid form multiplied by its fractional contribution to the absorption at the excitation wavelength. Assuming similar fluorescence quantum yield values to those obtained in acidified ethanol it is possible to estimate the fraction of absorption due to aggregates at $575 \mathrm{~nm}$ as being $76 \%, 78 \%, 66 \%, 61 \%$ and $78 \%$, respectively, for compound $\mathbf{4 a - d}$ and $\mathbf{5}$. As H-aggregates absorption occurs towards the blue of the monomer, these high aggregation levels explains the observed blue shift of the absorption spectra from ethanol to water whereas the opposite trend is observed in emission data (Table 1). The same reasoning explains the higher values of Stokes shifts observed in water when compared in ethanol.

In order to utilize the studied compounds either as dyes, fluorescent probes or biomarkers in fluorescence imaging it is important to evaluate their photostability in various conditions. Figure 3 shows the results of variations of absorption spectra of compounds $\mathbf{4 b}$ and 5 in water, BSA protein and soybean lecithin lipid membranes, upon irradiation with light at $600 \mathrm{~nm}$ obtained from a $200 \mathrm{~W}$ Xe arc-lamp filtered by an interference filter with $\sim 20 \%$ transmission at $600 \mathrm{~nm}$ and $10 \mathrm{~nm}$ fwhm.

\section{$<$ Figure 3>}

The photostability depends on the medium where the compound resides and increases in the order membranes $>$ BSA > water. Compound $\mathbf{5}$, which is disubstituted at the 9-amino position, is marginally more photostable than compound $\mathbf{4 b}$ (Figure 3E). In water, the compounds shows less photostability reaching $59 \%$ and $61 \%$ photodegradation for compounds $\mathbf{5}$ and $\mathbf{4 b}$ respectively, after $90 \mathrm{~min}$ irradiation. The H-aggregates are more photolabile as evident from the absorption spectra in water which show a red shift with an increase of the irradiation time (Figure 3A and 3B). In the studied models of biological media (Figure 3C and 
3D), no significant spectral changes are observed. Interestingly, the fraction of aggregation is higher in BSA than in membranes and is much higher for compound $\mathbf{4 b}$ than for compound $\mathbf{5}$. In BSA medium, the basic form is clearly seen at $\sim 510 \mathrm{~nm}$ only for compound $\mathbf{5}$ (Figure 3C). Both previous features and the slightly higher stability of compound $\mathbf{5}$ are probably a consequence of di-alkylation at 9-amino position. In BSA the photodegradation reaches only 19\% for compounds $\mathbf{5}$ and $\mathbf{4 b}$, respectively, after $50 \mathrm{~min}$ of irradiation. In soybean lecithin membranes, the photostability is very high reaching only $5 \%$ for compound $\mathbf{4 b}$ upon 110 min of irradiation, and no photodegradation was observed for compound 5 within 120 min of irradiation. Considering that light intensity used in the photostability experiment was $1.65 \mathrm{~mW}$ with a beam diameter of $8 \mathrm{~mm}, 120 \mathrm{~min}$ exposure corresponds to $59.4 \mathrm{~s}$ of irradiation with a 594 nm $2 \mathrm{~mW}$ HeNe laser with $0.8 \mathrm{~mm}$ beam diameter. Assuming $1 \mathrm{sec}$ acquisition time per pixel it would be possible to image a $8 \mathrm{~mm}$ circular zone with $800 \mu \mathrm{m}$ spatial resolution for more than 50 times, without significant photobleaching of compound $\mathbf{5}$ when incorporated in biological membranes. The spatial resolution can be improved by focusing the laser, but the field of view as well as the time per pixel needs to be reduced in order to not exceed the maximum number of photons per molecule during the acquisition of each picture. Considering the used experimental conditions in the photostability experiments, 120 min irradiation time corresponds to $5.95 \times 10^{-5}$ mol of photons. Each molecule within the irradiated cylinder, with 8 $\mathrm{mm}$ diameter and $1 \mathrm{~cm}$ length, was thus exposed, in average, to $1.2 \times 10^{4}$ photons per molecule without suffering appreciable photodegradation.

\section{Conclusion}

Four new benzo $[a]$ phenoxazinium chlorides possessing mono- or disubstituted amines with 3chloropropyl groups at the 9-position, isopropyl, cyclohexyl and phenyl groups as terminals at 
5-aminoposition of the polycyclic system were efficiently synthesised. The photophysical behaviour of these compounds was evaluated in dry ethanol and water. Acid base equilibria in ethanolic medium were found to be influenced by the presence of bulky groups in the 5-amino position. A hydroxyl group at the 2-position introduced an additional deprotonation site giving different photophysical behaviour for that type of compounds. The dialkylation at the 9-amino position mainly induced a red shift on the absorption and emission spectra and originated a higher percentage of the neutral basic form. Photostability studies showed that dialkylation at the 9-amino position induces a slightly higher resistance to photobleaching, H-aggregates showed more lability than monomers in water. Overall, based on the results obtianed, namely the absorption and fluorescence emission above $600 \mathrm{~nm}(600-700 \mathrm{~nm})$ and the good photostability particularly in biological media, the benzo[ $a]$ phenoxazinium chlorides described are potential interesting aleternative probes for bioapplications.

\section{Acknowledgments}

Thanks are due to the Fundação para a Ciência e Tecnologia (FCT, Portugal) for financial support to the NMR portuguese network (PTNMR, Bruker Avance III 400-Univ. Minho), FCT and FEDER (European Fund for Regional Development)-COMPETE-QREN-EU for financial support to Research Centres CQ/UM [PEst-C/QUI/UI0686/2013 (FCOMP-010124-FEDER-037302)] and CFUM [PEst-C/FIS/UI0607/2013 (F-COMP-01-0124-FEDER022711)]. Post-doctoral grant to B. R. Raju (SFRH/BPD/62881/2009) is also acknowledged to FCT, POPH-QREN, FSE. 


\section{References}

[1] Lie Z, Wang J, Tian Y, Song G, Zhao G, Xu H. Synthesis and application of clickable and biocompatible fluorescent glycosyl labels. Dyes Pigm 2015;113:627-633.

[2] Jayabharathi J, Karunakaran C, Kalaiarasi V, Ramanathan P, Prabhakaran A. Enhancing the photoluminescence of 1-(naphthalene-1-yl)-2,4,5-triphenyl-1H-imidazole anchored to superparamagnetic nanoparticles. Spectrochim Acta A 2015;135:1169-1172.

[3] Roubinet B, Renard P-Y, Romieu A. New insights into the water-solubilization of thiolsensitive fluorogenic probes based on long-wavelength 7-hydroxycoumarin scaffolds. Dyes Pigm 2014;110:270-284.

[4] Yuan L, Lin W, Yang Y, Chen H. A unique class of near-infrared functional fluorescent dyes with carboxylic-acid-modulated fluorescence ON/OFF switching: rational design, synthesis, optical properties, theoretical calculations, and applications for fluorescence imaging in living animals. J Am Chem Soc 2012;134:1200-1211.

[5] Yuan L, Lin W, Zhao S, Gao W, Chen B, He L, Zhu S. A unique approach to development of near-infrared fluorescent sensors for in vivo imaging. J Am Chem Soc 2012;134:1351013523.

[6] Yuan L, Lin W, Zheng K, He L, Huang W. Far-red to near infrared analyte-responsive fluorescent probes based on organic fluorophore platforms for fluorescence imaging. Chem Soc Rev 2013; 42: 622-661.

[7] Yang J, Li J, Hao P, Qui F, Liu M, Zhang Qi, Shi D. Synthesis, optical properties of multi donor-acceptor substituted AIE pyridine derivatives dyes and application for $\mathrm{Au}^{3+}$ detection in aqueous solution. Dyes Pigm 2015;116:97-105.

[8] Bridier A, Hammes F, Canette A, Bouchez T, Briandet R. Fluorescence-based tools for single-cell approaches in food microbiology. Int J Food Microbiol 2015; 213:2-16. 
[9] Ren J, Liu D, Tian L, Wei Y, Proksch P, Zeng J, Lin W. Venezuelines A-G, new phenoxazine-based alkaloids and aminophenols from Streptomyces venezuelae and the regulation of gene target Nur77. Bioorg Med Chem Lett 2013;23:301-04.

[10] Shi X-L, Ge J-F, Liu B-Q, Kaiser M, Wittlin S, Brun R, Ihara M. Synthesis and in vitro antiprotozoal activities of 5-phenyliminobenzo[a]phenoxazine derivatives. Bioorg Med Chem Lett 2011;21:5804-5807.

[11] Raju BR, Naik S, Coutinho PJG, Gonçalves MST. Novel Nile Blue derivatives as fluorescent probes for DNA. Dyes Pigm 2013;99:220-227.

[12] Link M, Kele P, Achatz DE, Wolfbeis OS. Brightly fluorescent purple and blue labels for amines and proteins. Bioorg Med Chem Lett 2011;21:5538- 5542.

[13] Fan J, Dong H, Hu M, Wang J, Zhang H, Zhu H, Sun W, Peng X. Fluorescence imaging lysosomal changes during cell division and apoptosis observed using Nile Blue based nearinfrared emission. Chem Commun 2014;50:882-884.

[14] Wang B, Fan J, Wang X, Zhu H, Wang J, Mua H, Penga X. A Nile blue based infrared fluorescent probe: imaging tumors that over-express cyclooxygenase-2. Chem Commun 2015;51:792-795.

[15] Raju BR, Firmino ADG, Costa ALS, Coutinho PJG, Gonçalves MST. Synthesis and photophysical properties of side-chain chlorinated benzo[ $[a]$ phenoxazinium chlorides. Tetrahedron 2013;69:2451-2461.

[16] Raju BR, Sampaio DMF, Silva MM, Coutinho PJG, Gonçalves MST. Ultrasound promoted synthesis of Nile Blue derivatives. Ultrason Sonochem 2014;21:360-366.

[17] Raju BR, Garcia AMF Costa ALS, Coutinho PJG, Gonçalves MST. Synthesis of new benzo $[a]$ phenoxazinium probes possessing carboxylic ester, hydroxyl and amino functional groups: photophysical studies in dry ethanol and conjugation with CdTe quantum dots. Dyes Pigm 2014;110,203-213. 
[18] Firmino ADG, Raju BR, Gonçalves MST. Microwave synthesis of water-soluble 2-,5- and 9-substituted benzo[a]phenoxazinium chlorides in comparison with conventional heating. Eur $\mathbf{J}$ Org Chem 2013;1506-1514.

[19] Firmino ADG, Gonçalves MST. Bifunctionalised long-wavelength fluorescent probes for biological applications. Tetrahedron Lett 2012;53:4946-4950.

[20] Alves CMA, Naik S, Coutinho PJG, Gonçalves MST. New long alkyl side-chain benzo[a]phenoxazines as micellisation probes. Tetrahedron Lett 2009;50:4470-4474.

[21] Frade VHJ, Sousa MJ, Moura JCVP, Gonçalves MST. Synthesis of naphtho[2,3a]phenoxazinium chlorides: structure-activity relationships of these heterocycles and benzo[a]phenoxazinium chlorides as new antimicrobials. Bioorg Med Chem 2008;16:32743282.

[22] Frade VHJ, Barros SA, Moura JCVP, Coutinho PJG, Gonçalves MST. Synthesis of short and long-wavelength functionalised probes: amino acids labelling and photophysical studies Tetrahedron 2007;63:12405-12418.

[23] Frade VHJ, Sousa MJ, Moura JCVP, Gonçalves MST. Synthesis, characterisation and antimicrobial activity of new benzo $[a]$ phenoxazine based fluorophores. Tetrahedron Lett 2007; 48:8347-8352.

[24] Frade VHJ, Gonçalves MST, Moura JCVP. Synthesis of fluorescent water-soluble functionalised benzo[ $a]$ phenoxazinium salts. Tetrahedron Lett 2006;47:8567-8570.

[25] Frade VHJ, Barros SA, Moura JCVP, Gonçalves MST. Fluorescence derivatisation of amino acids in short and long-wavelengths. Tetrahedron Lett 2007;48:3403-3407.

[26] Sens R, Drexhage K H. Fluorescence quantum yield of oxazine and carbazine laser dyes. J Luminesc 1981;24:709-712.

[27] Frade VHJ, Gonçalves MST, Coutinho PJG, Moura JCVP. Synthesis and spectral properties of long-wavelength fluorescent dyes. J Photochem Photobiol A: Chem 2007; 185:220-230. 
[28] Alves CMA, Naik S, Coutinho PJG, Gonçalves MST. Novel long alkyl side chain benzo $[a]$ phenoxazinium chlorides: synthesis, photophysical behaviour and DNA interaction. Tetrahedron 2009; 65:10441-10452.

[29] Streitwieser Jr A, Heathcook, CH. Introduction to organic chemistry, $2^{\text {nd }}$ ed. New York: Macmillan Pub; 1981. 


\section{CAPTIONS}

Scheme 1. Synthesis of benzo[a]phenoxazinium chlorides $\mathbf{4 a - d}$ and $\mathbf{5}$.

Table 1. Yields and photophysical data of compounds $\mathbf{4 a - d}$ and $\mathbf{5}$ in dry ethanol, acidified ethanol with TFA, basified ethanol with TEAH and in aqueous solution $\left(\mathrm{C}=1 \times 10^{-5} \mathrm{M}\right)$.

Table 2. Equilibrium dissociation constants of compounds $\mathbf{4 a - d}$ and $\mathbf{5}$ in dried ethanol.

Figure 1. Normalised absorption/emission spectra of compounds $4 \mathbf{a}-\mathbf{d}$ and $\mathbf{5}\left(\mathrm{C}=1 \times 10^{-5} \mathrm{M}\right)$ in water (A/B), ethanol (C/D) and either acidified or basified ethanol with respectively TFA or TEAH (E/F).

Figure 2. Absorption spectra of compounds $4 \mathbf{a}(\mathrm{A})$ and 5 (B) in dried ethanol media at concentrations from $7 \times 10^{-6} \mathrm{M}$ to $26 \times 10^{-6} \mathrm{M}$ (solid lines - experimental; grey lines - fitted spectrum); the dotted line is the spectrum of $1 \times 10^{-5} \mathrm{M}$ concentration in acidified ethanol; the dashed line is the spectrum correspondent to the basic form that, in the case of compound $\mathbf{4 a}$ (A) an additional spectrum represented by dash-dot-dot line is the fitted spectrum of the basic form that is involved in the acid-base equilibria. Panel $\mathrm{C}$ shows the obtained fraction of basic form of compounds $\mathbf{4 a - d}$ and $\mathbf{5}$ in anhydrous ethanol media.

Figure 3. Photostability experiments with $600 \mathrm{~nm}$ irradiation light. Normalised absorption spectra of compounds $\mathbf{4 b}$ and $\mathbf{5}$ in water (A, B), in BSA proteins (C) and in soybean lecithin membranes (D). Panel E shows the remaining fraction of molecules as a function of irradiation time with the inset representing the initial absorption of each studied system. 


\section{Scheme 1}

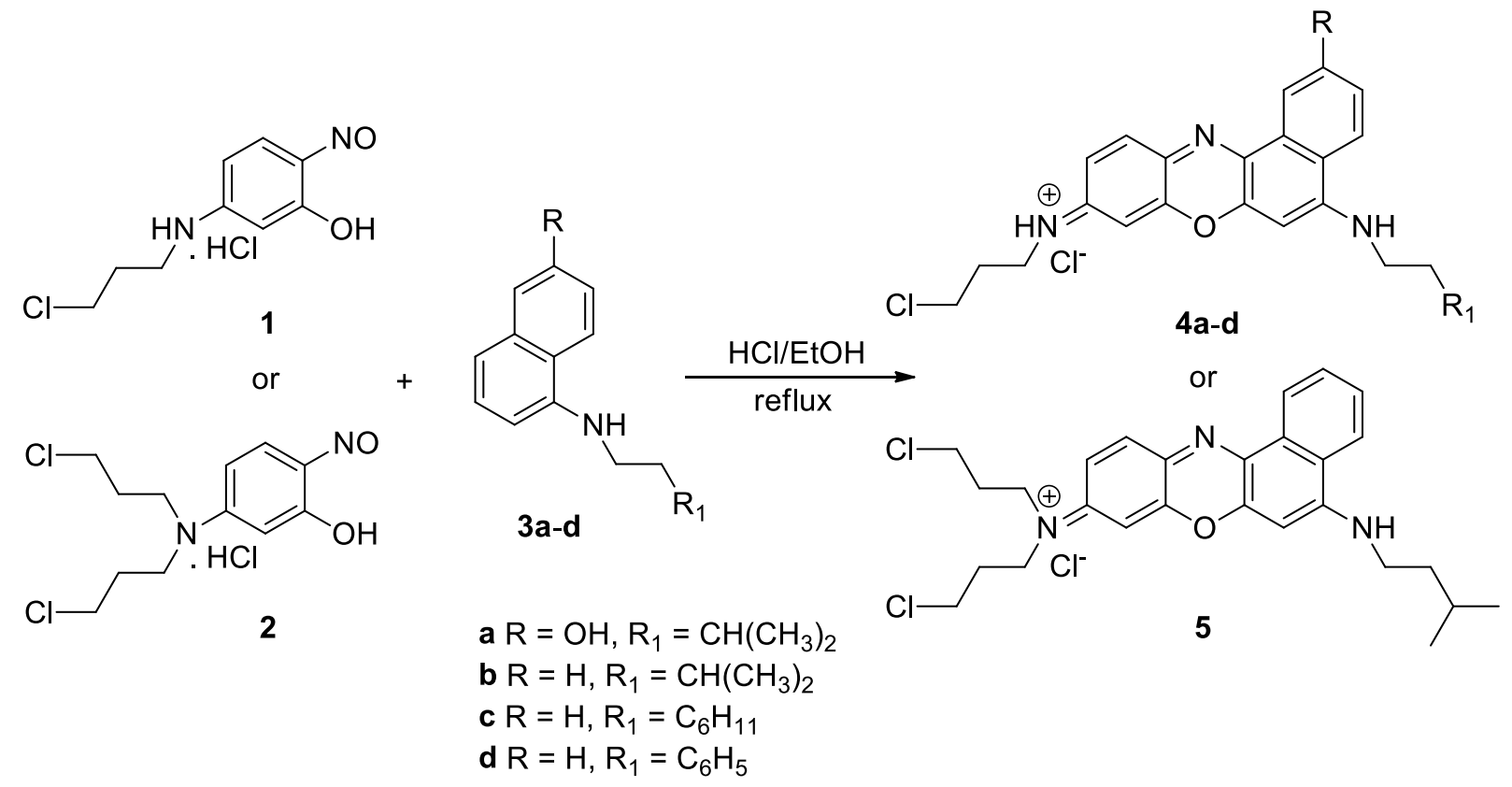


Table 1

\begin{tabular}{|c|c|c|c|c|c|c|c|}
\hline \multicolumn{3}{|c|}{ Compound } & $4 a$ & $4 b$ & $4 c$ & $4 d$ & 5 \\
\hline \multicolumn{3}{|c|}{ Yield (\%) } & 66 & 49 & 52 & 40 & 58 \\
\hline \multicolumn{8}{|l|}{ Solvent } \\
\hline \multicolumn{3}{|c|}{$\lambda_{\text {abs }}(\mathrm{nm})$} & 616 & 620 & 621 & 625 & 630 \\
\hline \multicolumn{3}{|c|}{$\varepsilon\left(10^{4} \mathrm{M}^{-1} \mathrm{~cm}^{-1}\right)$} & 2.5 & 0.8 & 1.1 & 1.6 & 0.4 \\
\hline \multirow[t]{4}{*}{ Ethanol } & \multicolumn{2}{|c|}{$\lambda_{\mathrm{em}} / / \mathrm{fwhm}(\mathrm{nm}){ }^{(a)}$} & $644 / / 55$ & $645 / / 50$ & $645 / / 50$ & $645 / / 52$ & $666 / / 56$ \\
\hline & $\Phi_{\mathrm{F}}$ & (a) & 0.11 & 0.36 & 0.38 & 0.45 & 0.40 \\
\hline & $\Delta(\mathrm{nm})$ & (a) & 28 & 25 & 24 & 20 & 36 \\
\hline & \multicolumn{2}{|c|}{$\lambda_{\mathrm{abs}} / / \mathrm{fwhm}(\mathrm{nm})$} & $617 / / 75$ & $619 / / 72$ & $620 / / 69$ & $623 / / 66$ & $628 / / 74$ \\
\hline \multirow{4}{*}{$\begin{array}{l}\text { Ethanol } \\
\text { acidified } \\
\text { with TFA }\end{array}$} & \multicolumn{2}{|c|}{$\varepsilon\left(10^{4} \mathrm{M}^{-1} \mathrm{~cm}^{-1}\right)$} & 5.2 & 3.7 & 4.9 & 5.2 & 4.3 \\
\hline & \multicolumn{2}{|c|}{$\lambda_{\mathrm{em}} / / \mathrm{fwhm}(\mathrm{nm})$} & $650 / / 69$ & $650 / / 61$ & $650 / / 62$ & $650 / / 64$ & $667 / / 64$ \\
\hline & $\Phi_{\mathrm{F}}$ & (a) & 0.38 & 0.46 & 0.47 & 0.45 & 0.44 \\
\hline & $\Delta(\mathrm{nm})$ & (a) & 33 & 31 & 30 & 27 & 39 \\
\hline \multirow{4}{*}{$\begin{array}{l}\text { Ethanol } \\
\text { basified } \\
\text { with TEAH }\end{array}$} & \multicolumn{2}{|c|}{$\lambda_{\mathrm{abs}} / / \mathrm{fwhm}(\mathrm{nm})$} & $482 / / 94$ & $493 / / 96$ & 493//92 & $497 / / 91$ & $499 / / 88$ \\
\hline & \multicolumn{2}{|c|}{$\varepsilon\left(10^{4} \mathrm{M}^{-1} \mathrm{~cm}^{-1}\right)$} & 2.6 & 1.7 & 2.1 & 2.5 & 1.9 \\
\hline & \multicolumn{2}{|c|}{$\lambda_{\mathrm{em}} / / \mathrm{fwhm}(\mathrm{nm}){ }^{(\mathrm{b})}$} & 622 & $611 / / 97$ & $610 / / 98$ & $611 / / 100$ & $611 / / 110$ \\
\hline & $\Phi_{\mathrm{F}}$ & (b) & 0.0004 & 0.021 & 0.027 & 0.027 & 0.019 \\
\hline & $\Delta(\mathrm{nm})$ & (b) & 140 & 118 & 117 & 114 & 112 \\
\hline \multirow{5}{*}{ Water } & \multicolumn{2}{|c|}{$\lambda_{\mathrm{abs}} / / \mathrm{fwhm}(\mathrm{nm})$} & $604 / / 166$ & $600 / / 116$ & $612 / / 106$ & $618 / / 94$ & $631 / / 95$ \\
\hline & \multicolumn{2}{|c|}{$\varepsilon\left(10^{4} \mathrm{M}^{-1} \mathrm{~cm}^{-1}\right)$} & 1.03 & 1.48 & 1.43 & 1.99 & 1.64 \\
\hline & \multicolumn{2}{|c|}{$\lambda_{\mathrm{em}} / / \mathrm{fwhm}(\mathrm{nm})^{(\mathrm{a})}$} & $650 / / 57$ & $653 / / 56$ & $653 / / 58$ & $656 / / 60$ & $677 / / 62$ \\
\hline & $\Phi_{\mathrm{F}}$ & (a) & 0.089 & 0.10 & 0.16 & 0.18 & 0.098 \\
\hline & $\Delta(\mathrm{nm})$ & (a) & 46 & 53 & 41 & 38 & 46 \\
\hline
\end{tabular}

(a) Emission spectra obtained with excitation at $575 \mathrm{~nm}$; (b) Emission spectra obtained with excitation at $470 \mathrm{~nm}$ 
Table 2

\begin{tabular}{lccccc}
\hline Compound & $\mathbf{4 a}^{(*)}$ & $\mathbf{4 b}$ & $\mathbf{4 c}$ & $\mathbf{4 d}$ & $\mathbf{5}$ \\
\hline $\mathrm{K}_{\mathrm{a}}\left(10^{-5} \mathrm{M}\right)$ & 1.1 & 4.5 & 2.7 & 3.2 & 7.2 \\
\hline
\end{tabular}

(*) Obtained by fitting the absorption spectrum of the basic form 
Figure 1

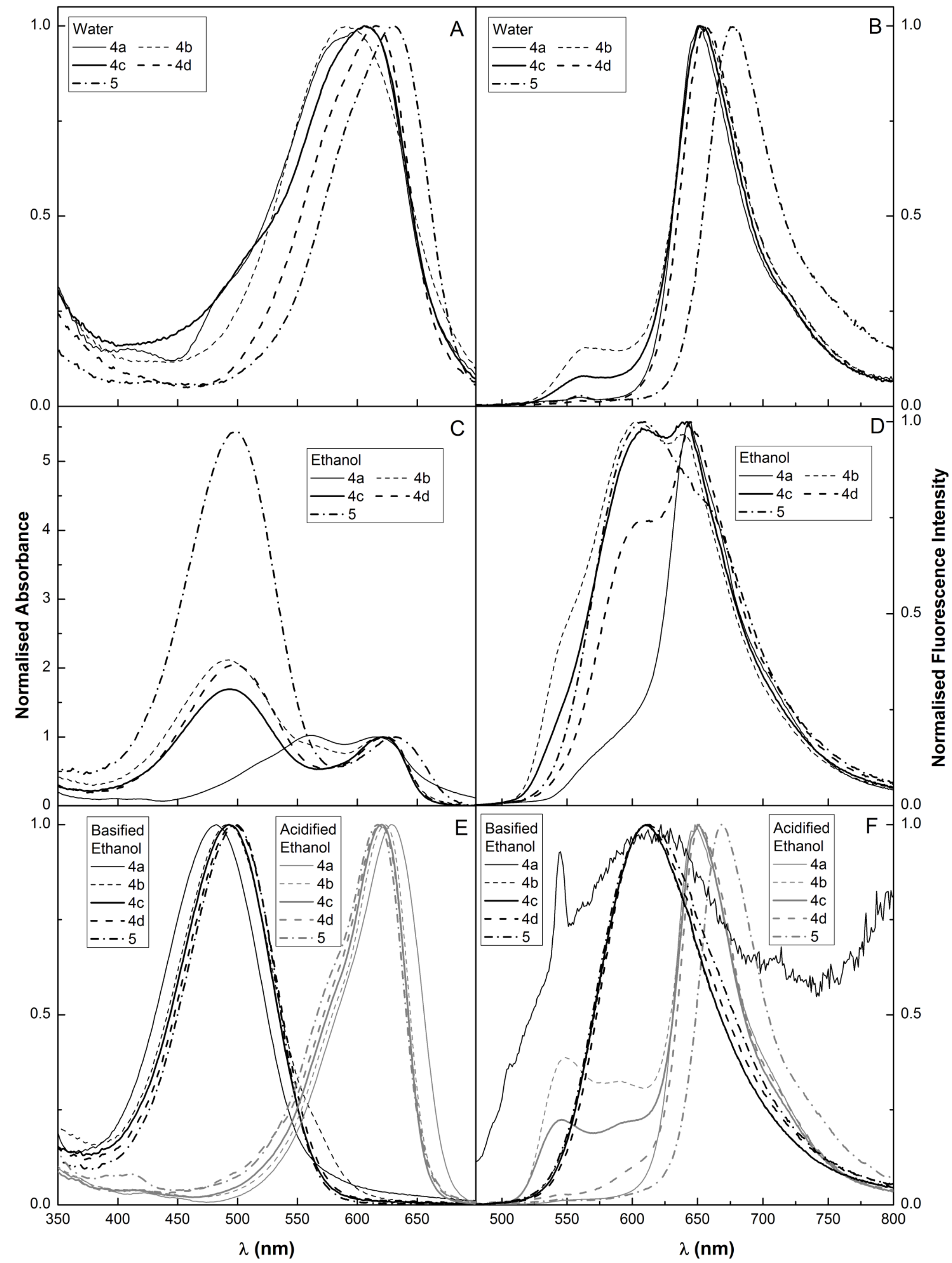




\section{Figure 2}
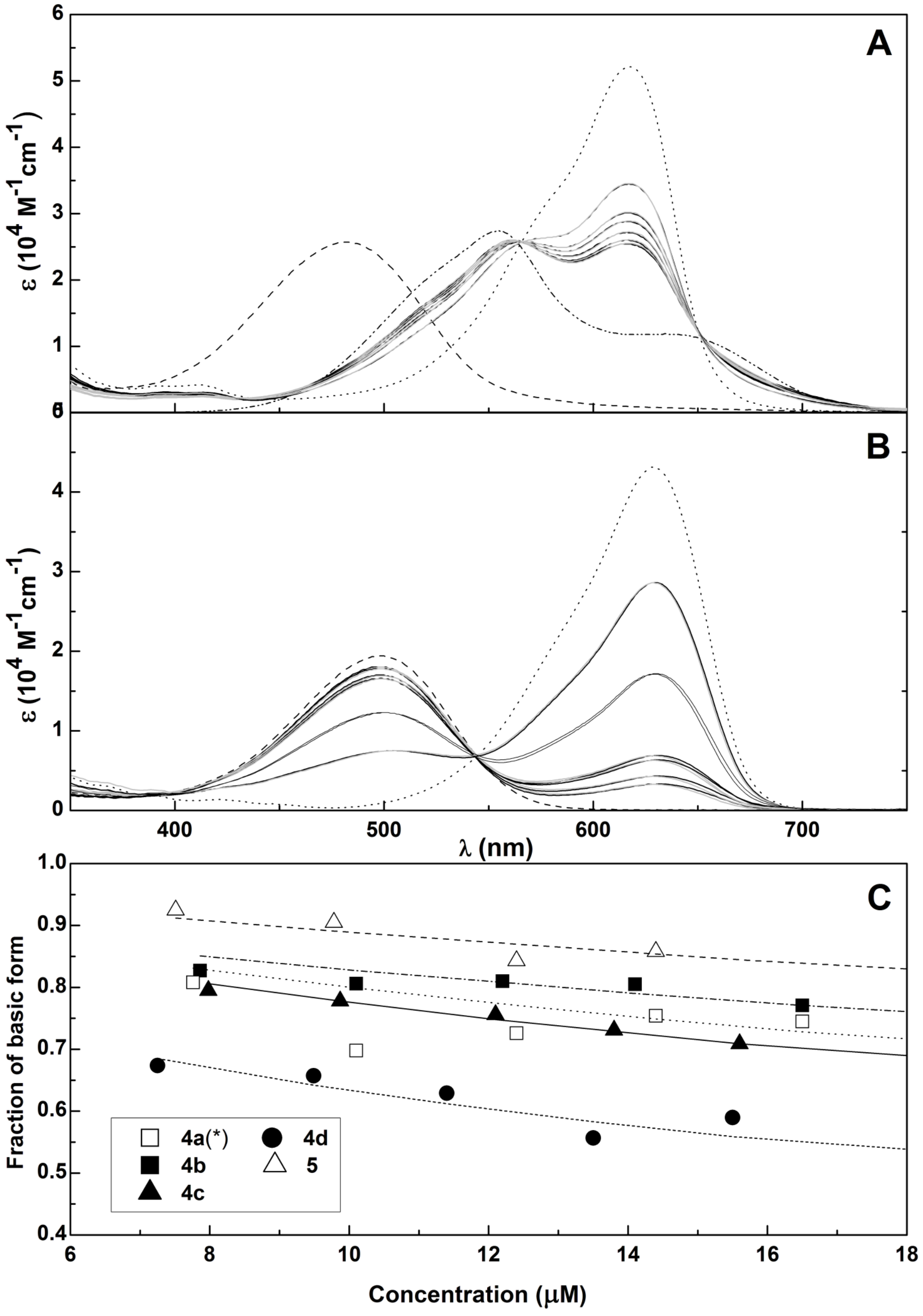
Figure 3
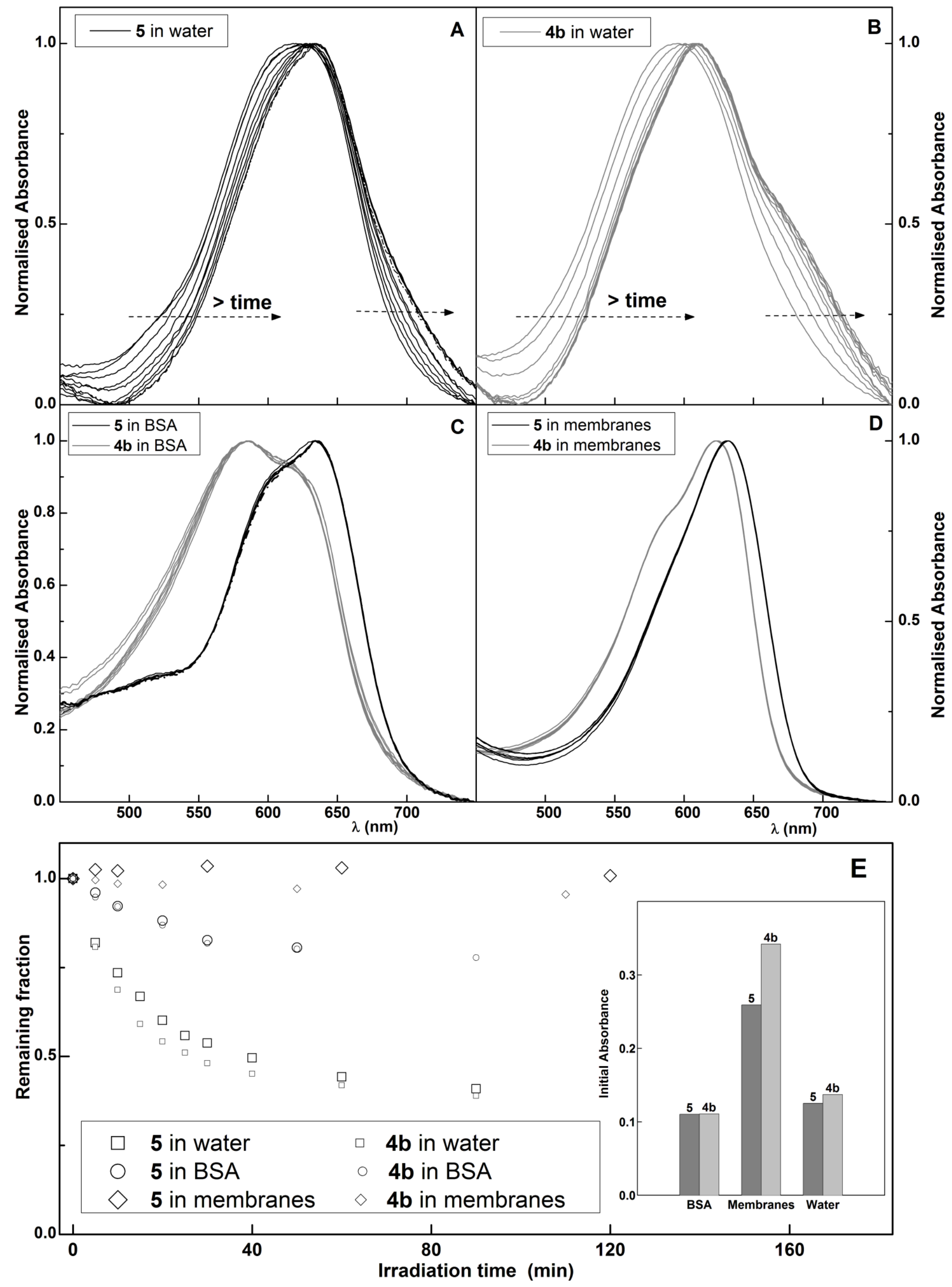